\title{
OPTIMIZATION OF STRAWBERRY DRYING PROCESS UNDER DIFFERENT PRETREATMENTS AND GEOMETRIES AT LOW TEMPERATURES
}

\author{
${ }^{1}$ Ghaly, A., ${ }^{2}$ Nakib, A., ${ }^{3}$ AbdelMwla, H., ${ }^{4}$ Nagy, K. and ${ }^{5}$ Hassan, A.
}

\section{ABSTRACT}

The drying kinetics of strawberry were investigated and optimized. They affected by the strawberry geometries and the drying temperature in addition to the pretreatments including the thermal treatments and osmotic dehydration. Three geometries (whole, halve and quarter), two thermal pretreatments (hot water and microwave), osmotic dehydration (sucrose + calcium chloride and glucose + calcium chloride) and three temperatures $\left(40,50\right.$ and $\left.60^{\circ} \mathrm{C}\right)$ were evaluated. The initial moisture content of the fresh strawberry samples was varied between 93.4 and 77 $\%$ (w.b). The results indicated that the half that treated by sucrose, Whole that treated by sucrose and hot water $\left(80^{\circ} \mathrm{C}\right)$ for $10 \mathrm{sec}$ and half that treated by glucose, microwave $(1100 \mathrm{~W})$ for $10 \mathrm{sec}$ at $40^{\circ} \mathrm{C}$. Also, half that treated by glucose, whole that treated by sucrose and hot water $\left(80{ }^{\circ} \mathrm{C}\right)$ for $10 \mathrm{sec}$ and whole that treated by sucrose, microwave (1100 W) for $10 \mathrm{sec}$ at $50^{\circ} \mathrm{C}$. The optimum conditions at the highest temperature $60{ }^{\circ} \mathrm{C}$ were half that treated by sucrose, whole that treated by sucrose and hot water $\left(80^{\circ} \mathrm{C}\right)$ for $10 \mathrm{sec}$ and whole that treated by sucrose, microwave $(1100 \mathrm{~W})$ for $10 \mathrm{sec}$.

Keywords: Strawberry, Geometry, dehydration, Shrinkage, optimization.

\section{INTRODUCTION}

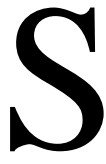
trawberry (Fragaria $\times$ ananassa) is a widely grown hybrid species and one of an important and common fruit contents a highly amounts of essential substances for healthy growth with prefered sensory characteristic (Ghaly et al., 2015). The strawberry production has increased markedly either local (Egypt) or wide world furthermore the cultivated land.

1 Prof. Emeritus of Biological and Environmental Engineering, Dalhousie University, Canada

2 Prof. of Agricultural Engineering, Fac. of Agri. Eng., Al-Azhar University. Cairo

3 Prof. of Agricultural Engineering, Fac. of Agri. Eng., Al-Azhar University., Assiut.

4 Prof. of Food Processing and Packaging. Agriculture Research Center, Giza

5 lecturer assistant, Fac. of Agri. Eng., Al-Azhar University., Assiut. 
The production increased from 242776 tonnes in 2009 to 254921 tonnes in 2013. The total production of strawberry amount to about 242297 tonnes cultivated in 13.889 thousand feddans (FAO, 2015). Also, the importance of strawberry that is consumed as fresh or widely used in the processed products (Menager and Aubert, 2004).

Preservation strawberry is urgent, because it is highly delicate nature and perishable fruit addition to decline in nutritional contents and spoil rapidly. Dehydration is the major method to preserve the strawberry by decreasing the moisture contain and inhibit the microbial and enzymatic activities (Grabowski et al., 2003). There are many ways to dehydrate the strawberry. However, the methods are different in the drying time, costs, the final sensory characteristic and the nutrient remaining. The osmotic dehydration partial reduces the water activity, enhances the taste and appearance and the nutrient remaining addition to the ability of using with other methods in combine or in serial without significant costs (Chavan, 2012).

There are many factors affecting the osmotic treatment including temperature, osmotic solution concentration, holding time in the solution, type of osmotic agent, osmotic solution : fruit ratio, shape and any pretreatment as thermal and/or mechanical (Panarese et al., 2012). Although the higher temperature get a positive effect on moisture diffusivity and decrease the drying time, but it get a bad affects in the nutritional quality of the final product (Noshad et al., 2012).

The pretreatment before the drying used to improve the drying methods including thermal and non-thermal (Wiktor et al., 2014). Immersion of the fruits or the vegetables in hot water for appropriate time is enough to destroy the enzymes present in the tissue, stop the enzymatic action, retain the color and shorten the drying time (Vadivambal and Jayas, 2007). Also, exposing the fruits or the vegetables to the microwave assists the drying process and enhances the color. Nieto et al. (2004) and Mayor et al. (2011) mention that the structural changes refer to the quality of drying.

The Objective: The aim of this study was to optimize the drying behavior of strawberry at different geometries (whole, half and quarter), 
pretreatments: thermal (hot water and microwave) and osmosis (sucrose + calcium chloride and glucose + calcium chloride) at low drying temperatures $\left(40,50\right.$ and $\left.60{ }^{\circ} \mathrm{C}\right)$.

\section{MATERIALS AND METHODS}

\section{Strawberry Samples.}

The strawberries were obtained from local markets in Halifax, Nova Scotia, Canada. The fruits were refrigerated at a temperature of $4^{\circ} \mathrm{C}$ until used in the experiments during the first $24 \mathrm{~h}$ form production date. The strawberries were washed and the peduncles were removed before use.

\section{Preparation of Strawberry Geometries.}

Three different geometric shapes were used in this study (whole, half, and fourth). Individual strawberries were cut vertically using a sharp knife into two halves. Finally, each half was divided again into two parts (quarters). Figure 1 shows the three geometries. A digital vernier caliper (Chen Tech Electronic Caliper, Harbor Freight Tools, Camarillo, California, USA) with $0.01 \mathrm{~mm}$ sensitivity was used for measuring the dimensions of strawberry geometric shapes.

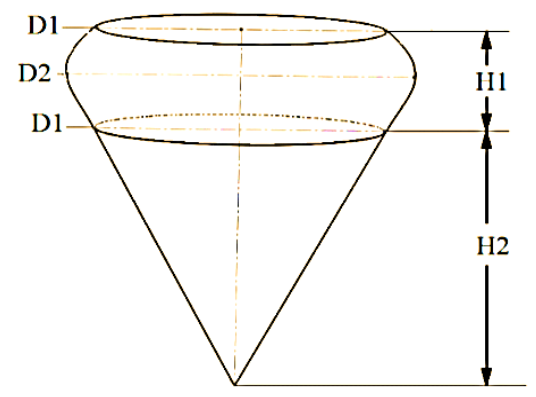

(a)Whole

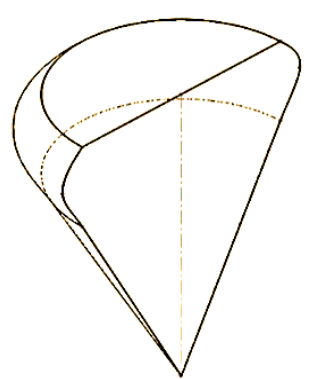

(b) Half

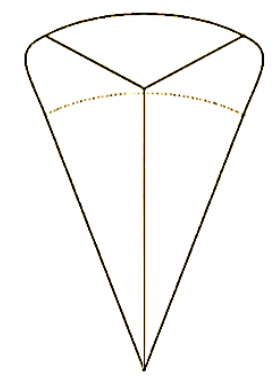

(c) Quarter

Figure 1. The assumed shape of strawberry geometries (Ghaly et al., 2015).

\section{Experimental Protocol}

Control Experiments: there are three groups (no pre-treatment, pretreated in hot water and pretreated in microwave). Each group contains various strawberry geometries (whole, half and quarter) in triplicates. The initial mass of each strawberry shape was determined and placed in hot air the oven (OMS100, Thermo Fisher Scientific, Ottawa, Ontario, Canada) at 
selected temperature $\left(40{ }^{\circ} \mathrm{C}\right)$. The samples were taken from the oven and weighed at regular time intervals $4 \mathrm{~h}$ during the first $24 \mathrm{~h}, 6 \mathrm{~h}$ during the next $24 \mathrm{~h}$ and $12 \mathrm{~h}$ up to the stable mass (the decline in the mass less than $0.01 \mathrm{~g}$ (Menlik et al., 2010)). The procedure of the different samples were repeated at temperatures of $50{ }^{\circ} \mathrm{C}$ and $60^{\circ} \mathrm{C}$.

Pre-treatments: There are two different pre-treatments of strawberry samples were applied (blanching in hot water at $80{ }^{\circ} \mathrm{C}$ for 10 seconds and exposing to microwaves at 1100 Watt for 10 seconds) the weighs were carried out at every samples of the strawberry geometries (whole, half and fourth). The strawberries were weighed to determine the changes in weight before and after the pretreatment.

Osmotic Pretreatment: There are two different osmotic pre-treatments were used (500 $\mathrm{g}$ sucrose $+10 \mathrm{~g} \mathrm{CaCl}_{2}$ dissolved in $1 \mathrm{~L}$ distilled water and $500 \mathrm{~g}$ glucose $+10 \mathrm{~g} \mathrm{CaCl}_{2}$ dissolved in $1 \mathrm{~L}$ distilled water) as a pre-dehydration of the strawberry samples. The samples : solution ration did not less than 1:5 (mass basis) to insure the samples were immersed and avoid the changes in the solution concentration during the osmotic dehydration. The contact time was $2 \mathrm{~h}$ at room temperature $\left(20^{\circ} \mathrm{C}\right)$. Each of the various strawberry geometries (whole, half and fourth) was placed in pre-weighted dish. The dish and strawberry were weight to determine the changes in weight of strawberry after the pretreatment and after osmotic pre-dehydration.

The Hot Air Drying: The strawberry samples were placed into hot air oven at the selected temperature of $60{ }^{\circ} \mathrm{C}$. The dish and treated strawberries were taken from the oven at regular time intervals $(4 \mathrm{~h})$ and weighed. The procedure was repeated until the weight of the dish and strawberry remained constant. The entire procedure was repeated for the strawberry samples dried at the temperatures of $40{ }^{\circ} \mathrm{C}$ and $50{ }^{\circ} \mathrm{C}$.

The following analyses were performed on the fresh strawberry samples and the dried samples at the different geometries (whole, halve and quarter) to optimize the drying conditions.

\section{Strawberry Volume}

The shape of the strawberry was assumed by Ghaly et al. (2015) to be a cone on the top of a disc. They proposed equations $1-3$ to calculate the volume for the various strawberry geometries. 


$$
\begin{array}{lr}
\text { Whole volume }=\frac{1}{3} \pi \mathrm{H}_{2}\left(\frac{\mathrm{D}_{1}}{2}\right)^{2}+\pi \mathrm{H}_{1}\left(\frac{\left(\mathrm{D}_{1}+\mathrm{D}_{2}\right)}{4}\right)^{2} & 1 \\
\text { Half volume }=\frac{1}{2}\left[\frac{1}{3} \pi \mathrm{H}_{2}\left(\frac{\mathrm{D}_{1}}{2}\right)^{2}+\pi \mathrm{H}_{1}\left(\frac{\left(\mathrm{D}_{1}+\mathrm{D}_{2}\right)}{4}\right)^{2}\right] & 2 \\
\text { Quarter volume }=\frac{1}{4}\left[\frac{1}{3} \pi \mathrm{H}_{2}\left(\frac{\mathrm{D}_{1}}{2}\right)^{2}+\pi \mathrm{H}_{1}\left(\frac{\left(\mathrm{D}_{1}+\mathrm{D}_{2}\right)}{4}\right)^{2}\right] & 3
\end{array}
$$

Where: $\mathrm{D}_{1}, \mathrm{D}_{2}, \mathrm{H}_{1}$ and $\mathrm{H}_{2}$ were the geometric dimensions (mm) as shown in Figures 1

\section{The Shrinkage}

The shrinkage of dried strawberry samples was calculated according to Nieto et al. (2004) Equation as the following:

$$
\text { Shrinkage }=\frac{V_{0}-\mathrm{V}}{V_{0}} \times 100
$$

Where: $\mathrm{V}_{0}=$ the initial volume $\left(\mathrm{mm}^{3}\right), \mathrm{V}=$ the volume after drying $\left(\mathrm{mm}^{3}\right)$.

\section{Moisture Content (wet basis).}

The moisture content on wet basis was calculated as follows:

$$
M_{c}=\frac{M_{i}-M_{f}}{M_{i}} \times 100
$$

Where: $\mathrm{M}_{\mathrm{c}}=$ moisture content $(\%), \mathrm{W}_{\mathrm{i}}=$ initial mass of sample $(\mathrm{g}), \mathrm{W}_{\mathrm{f}}=$ final weight of sample $(\mathrm{g})$

\section{Drying Rate.}

The drying rate was calculated as follows:

$$
M R=\frac{M_{t}-M_{e}}{M_{0}-M_{e}}
$$

Where: $\mathrm{MR}=$ drying rate $(\mathrm{g}$ water/ $\mathrm{g}$ dried material $), \mathrm{M}_{\mathrm{t}}=$ moisture contents after time $(\mathrm{t})(\%), \mathrm{t}=$ time of weighted sample $(\mathrm{h}: \mathrm{m}), \mathrm{M}_{0}=$ initial moisture contents $(\%), \mathrm{Me}=$ equilibrium moisture contents $(\%)$.

The average drying rates were taken from three replicates in each experimental. They calculated by dividing the total amount of moisture removed by the drying time of equilibrium weight.

\section{The optimization of drying kinetic}

The dying kinetics was optimized by using t-test for Two Assuming Unequal Variances as the following Equation:

$$
\boldsymbol{t}=\frac{\bar{x}_{D}-\mu_{0}}{S_{D} / \sqrt{n}}
$$

Where: $\bar{\chi}_{\mathrm{D}}=$ mean differences, $\mu_{0}=$ hypothesize, $\mathrm{S}_{\mathrm{D}}=$ standard deviation, $\mathrm{n}=$ number of variances. 


\section{RESULTS AND DISCUSSIONS}

The changes in moisture content with time and shrinkage ratio for the various strawberry geometries at the different pretreatments and temperatures were studied and proposed for optimizing the drying kinetics as the following:

\section{Moisture Content, Drying Rate and Drying Factor}

The initial moister content was calculated for every samples which varied between 93.4 and $77 \%$ (w.b). The measured weights were recorded during drying of different geometry strawberries (whole, half and quarter) at the pretreatments (hot water and microwave) or/and the osmotic dehydration (sucrose $+\mathrm{CaCl}_{2}$ and glucose $+\mathrm{CaCl}_{2}$ ) at different temperatures $\left(40,50\right.$ and $\left.60{ }^{\circ} \mathrm{C}\right)$. The geometry caused the differences in weight, surface area, cut area and volume to the same sample. The results were in agreement with Ghaly et al. (2015). The optimum kinetics as shown in Table 1.

Table 1. Initial properties of strawberry at different geometries.

\begin{tabular}{|c|c|c|c|c|c|c|c|c|c|}
\hline $\mathrm{T}$ & $\operatorname{Pr}$ & Geometry & $\mathrm{Ot}$ & $\begin{array}{l}\text { Weight } \\
\text { (g) }\end{array}$ & $\begin{array}{c}\text { Surface } \\
\text { Area }\end{array}$ & $\begin{array}{l}\text { Cut } \\
\text { Area }\end{array}$ & $\begin{array}{c}\text { Volume } \\
\left(\mathrm{cm}^{3}\right)\end{array}$ & $\begin{array}{c}\text { Area/ } \\
\text { Weight }\end{array}$ & $\begin{array}{c}\text { Area/ } \\
\text { Volume }\end{array}$ \\
\hline \multirow[t]{3}{*}{40} & NR & Half & $\mathrm{S}$ & 10.4799 & 28.1430 & 7.2121 & 8.989 & 2.6854 & 0.2987 \\
\hline & $\mathrm{H}$ & Whole & S & 11.8730 & 26.8748 & 0.0000 & 11.436 & 2.2635 & 0.1979 \\
\hline & M & Half & G & 13.6874 & 34.4059 & 6.3591 & 10.627 & 2.5502 & 0.3258 \\
\hline \multirow[t]{3}{*}{50} & NR & Half & G & 11.6171 & 24.5920 & 6.3899 & 8.445 & 2.1685 & 0.2874 \\
\hline & $\mathrm{H}$ & Whole & S & 16.1133 & 40.0487 & 0.0000 & 18.203 & 2.0715 & 0.1046 \\
\hline & M & Whole & $\mathrm{S}$ & 22.8287 & 44.7143 & 0.0000 & 23.777 & 1.9587 & 0.0824 \\
\hline \multirow[t]{3}{*}{60} & NR & Half & $S$ & 9.5126 & 24.4347 & 6.1600 & 7.362 & 2.5687 & 0.3489 \\
\hline & $\mathrm{H}$ & Whole & S & 15.1260 & 41.7041 & 0.0000 & 14.232 & 2.0101 & 0.1412 \\
\hline & M & Whole & $\mathrm{S}$ & 20.1499 & 49.1043 & 0.0000 & 20.786 & 1.9407 & 0.0934 \\
\hline
\end{tabular}

Where: $\mathrm{S}=$ treatment with sucrose, $\mathrm{G}=$ treatment with glucose, $\mathrm{NR}=$ no pretreatment, $\mathrm{H}=$ pretreatment using hot water at $80^{\circ} \mathrm{C}$ for $10 \mathrm{sec}, \mathrm{M}=$ pretreatment using microwave at $1100 \mathrm{~W}$ for $10 \mathrm{sec}, \mathrm{T}=$ tempreture $(\mathrm{C}), \mathrm{Ot}=$ osmotic treatment, $\operatorname{Pr}=$ pretreatment.

Verma et al. model was the best model describing the drying rates of strawberry. The drying factor was obtained from the model as "k" coefficient as shown in Table 3. The Figure 2 showed the drying rates at the optimum conditions. And the verma et al. model showed as the following Equation:

$M R=a \cdot \exp (-k t)+(1-a) \exp (-g t)$

Where: $\mathrm{k}=$ drying coefficient $\left(\mathrm{h}^{-1}\right), \mathrm{t}=$ time $(\mathrm{h})$, a and $\mathrm{g}=$ dimensionless coefficients. 
PROCESS ENGINEERING
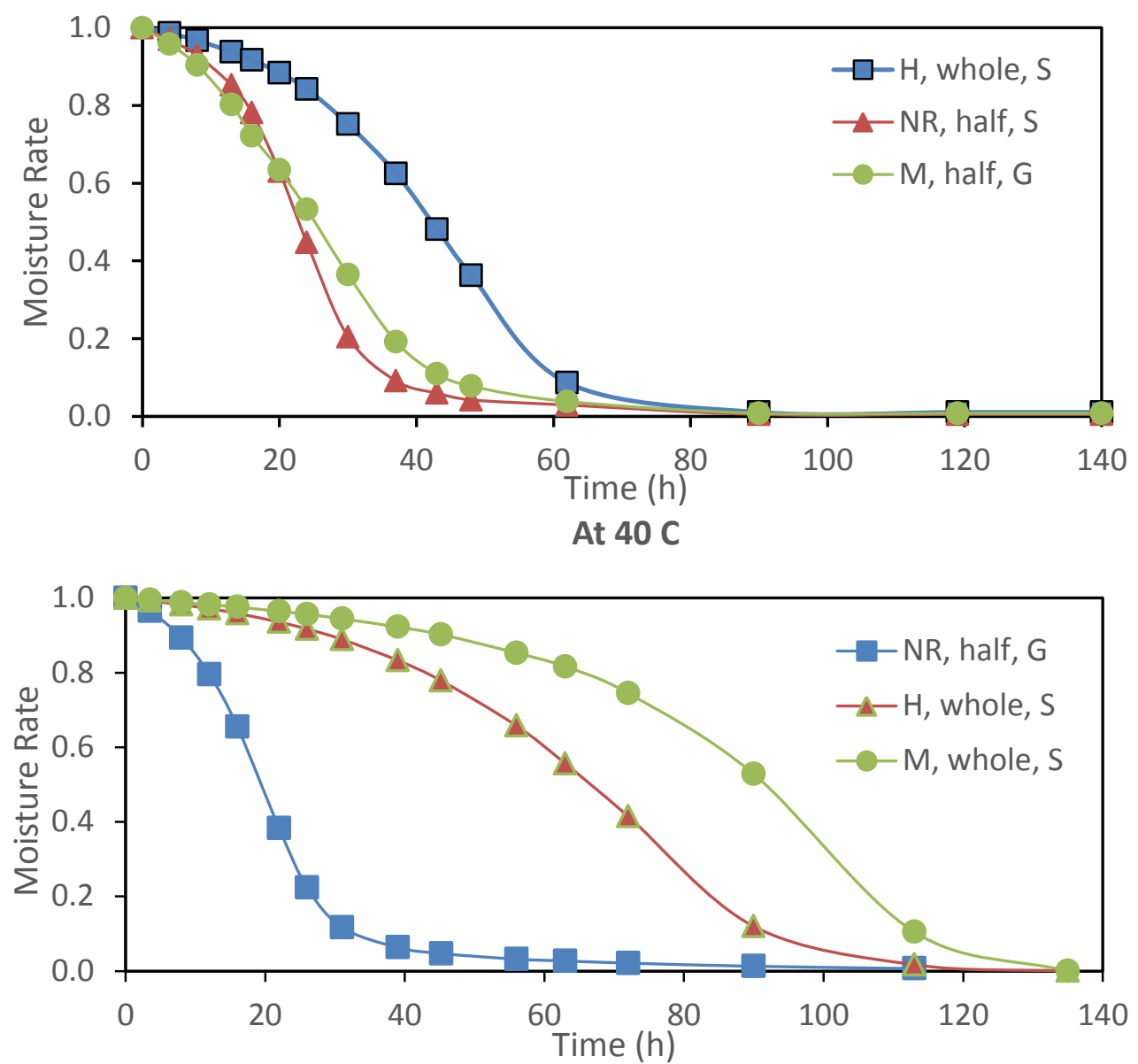

At $50 \mathrm{C}$

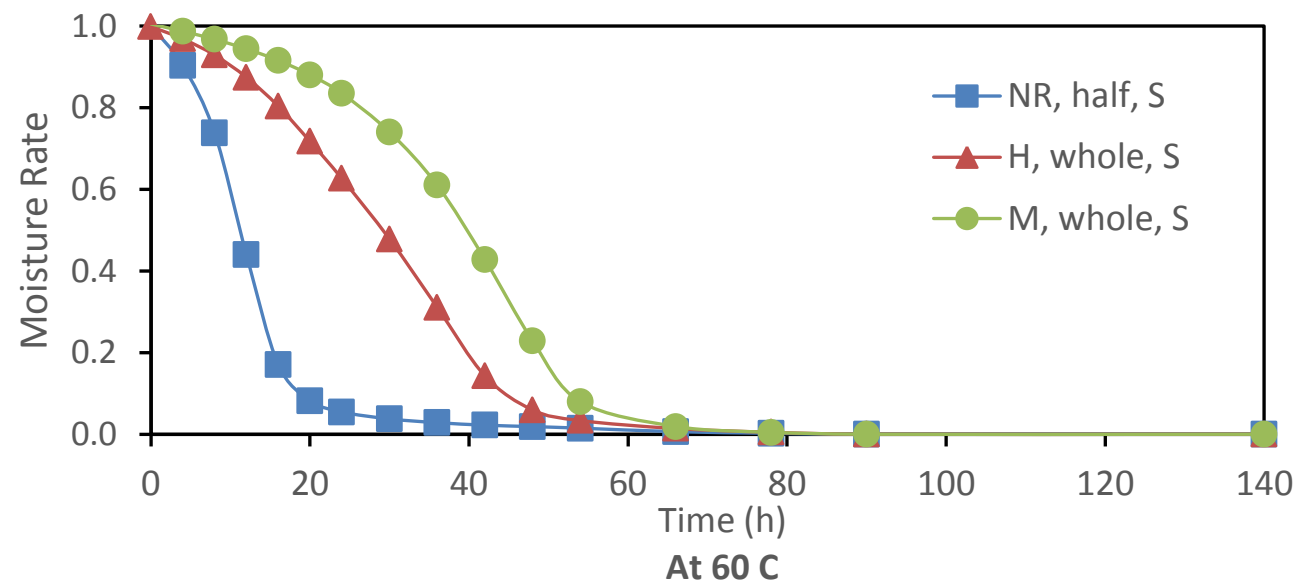

Figure 2. The drying rates at the optimum drying kinetic conditions. 


\section{Volume and Shrinkage Ratio}

The initial mean volume was recorded for all geometry fresh samples and dried at the different pretreatments and temperatures. The results showed that the volume and the drying time were in a direct relationship. Increasing the surface area due to a faster decrease in the moisture content over the drying time. Krokida et al. (2003), Brooks et al. (2008) and Ghaly et al. (2015) reported similar results while drying tomato and strawberry of various geometries and temperatures. The highest and lowest volumes for the fresh samples were 22.3819 and $11.4361 \mathrm{~mm}^{3}$ for whole, 10.6277 and $7.2320 \mathrm{~mm}^{3}$ for half and 12.3213 and $2.7241 \mathrm{~mm}^{3}$ for quarter. Also, the highest and lowest volumes for the dried samples were 22.3819 and $11.4361 \mathrm{~mm}^{3}$ for whole, 10.6277 and $7.2320 \mathrm{~mm}^{3}$ for half and 12.3213 and $2.7241 \mathrm{~mm}^{3}$ for quarter as shown in Table 2. The Shrinkage ratio was dependent on the temperature and sample geometry in all dried strawberry samples and was independent with both of the thermal and the osmotic pre-treatments. The results showed that the strawberry samples dried at low temperature had higher shrinkage values than those dried at the lower temperature and increasing the sample size resulted in lower shrinkage at all temperatures. Moisture get out from the pores and the cell faster than deformation in the texture. The result was in agreement with Agnieszka and Andrzej (2010). it was varied from 11\% at $60{ }^{\circ} \mathrm{C}$ to $87 \%$ at $40{ }^{\circ} \mathrm{C}$ for whole, from $34 \%$ at $60{ }^{\circ} \mathrm{C}$ to $87 \%$ at $40{ }^{\circ} \mathrm{C}$ for half and $75 \%$ at $60{ }^{\circ} \mathrm{C}$ to $96 \%$ at $40{ }^{\circ} \mathrm{C}$ for quarter.

\section{Specific Drying Time}

The specific drying time was calculated according to volume by dividing the drying time by the sample volume as shown in Figures 3. It referred to the required time to dry $1 \mathrm{~cm}^{3}$ of fresh strawberry to a constant weight. The results showed that the specific drying time was in a direct relationship with the volume. They were $3.2,1.7$ and $1.1 \mathrm{~h} / \mathrm{cm}^{3}$ in the highest values to $0.7,0.4$ and $0.3 \mathrm{~h} / \mathrm{g}$ in the lowest values for whole, half and quarter. Also, the specific drying time was affected by temperature in an inverse relationship. The specific drying time was used to adjust the relationship between the volume unit per time unit and to give a total time of drying time as Grove et al. (1985) reported while drying the strawberry and Erenturk et al. (2005) during drying rosehips. 


\section{The optimization of drying kinetic}

The drying kinetics were proposed in 81 experiments (27 control and 54 the treatments) as shown in Table 3 and optimized statically by using ttest for Two Assuming Unequal Variances. It was used to fit data for other relevant variances, such as the shrinkage ratio and the drying factor in order to describe the change in both of volume and moisture content for optimum drying kinetic. This will determine whether each of these factors was independently associated with the drying rate as Riediger et al. (2007) mentioned. The results showed that the optimum drying kinetics were 9 according to the various geometries, thermal pretreatments, osmotic dehydration and drying temperatures.

Table 2. The shrinkage ratio of different strawberry geometries at various

pretreatments, osmotic dehydration and temperatures

\begin{tabular}{|c|c|c|c|c|c|c|c|c|c|c|c|}
\hline \multirow{2}{*}{$\begin{array}{c}\text { Osmo- } \\
\text { treatment }\end{array}$} & \multirow{2}{*}{$\begin{array}{c}\text { Pre- } \\
\text { treatment }\end{array}$} & \multirow{2}{*}{$\begin{array}{c}\text { Temp } \\
\left({ }^{\circ} \mathrm{C}\right)\end{array}$} & \multicolumn{3}{|c|}{ whole } & \multicolumn{3}{|c|}{ have } & \multicolumn{3}{|c|}{ quarter } \\
\hline & & & $\begin{array}{c}\mathrm{V} 1 \\
\left(\mathrm{~cm}^{3}\right)\end{array}$ & $\begin{array}{c}\mathrm{V} 2 \\
\left(\mathrm{~cm}^{3}\right)\end{array}$ & $\begin{array}{c}\mathrm{Sr} \\
(\%)\end{array}$ & $\begin{array}{l}\mathrm{V} 1 \\
\left(\mathrm{~cm}^{3}\right)\end{array}$ & $\begin{array}{l}\mathrm{V} 2 \\
\left(\mathrm{~cm}^{3}\right)\end{array}$ & $\begin{array}{l}\mathrm{Sr} \\
(\%)\end{array}$ & $\begin{array}{l}\mathrm{V} 1 \\
\left(\mathrm{~cm}^{3}\right)\end{array}$ & $\begin{array}{l}\mathrm{V} 2 \\
\left(\mathrm{~cm}^{3}\right)\end{array}$ & $\begin{array}{l}\mathrm{Sr} \\
(\%)\end{array}$ \\
\hline \multirow[t]{9}{*}{ NO } & NR & 40 & 14.4 & 2.76 & 81 & 7.74 & 0.98 & 87 & 4.07 & 0.29 & 93 \\
\hline & & 50 & 16.4 & 5.86 & 64 & 9.74 & 2.64 & 73 & 6.07 & 0.46 & 92 \\
\hline & & 60 & 14.0 & 7.69 & 45 & 8.56 & 3.79 & 56 & 5.98 & 0.64 & 89 \\
\hline & $\mathrm{H}$ & 40 & 14.1 & 3.45 & 76 & 7.27 & 2.62 & 64 & 2.53 & 0.45 & 82 \\
\hline & & 50 & 22.2 & 7.08 & 68 & 6.45 & 2.96 & 54 & 3.63 & 0.71 & 81 \\
\hline & & 60 & 14.3 & 6.00 & 58 & 9.99 & 5.89 & 42 & 2.76 & 0.66 & 76 \\
\hline & $\mathrm{M}$ & 40 & 13.1 & 3.74 & 71 & 6.50 & 1.37 & 79 & 2.91 & 0.47 & 84 \\
\hline & & 50 & 20.5 & 9.79 & 52 & 6.88 & 2.07 & 70 & 4.21 & 0.81 & 81 \\
\hline & & 60 & 15.8 & 11.0 & 30 & 8.62 & 3.59 & 58 & 2.68 & 0.66 & 75 \\
\hline \multirow[t]{9}{*}{$S$} & NR & 40 & 14.6 & 2.45 & 83 & 8.99 & 1.64 & 82 & 2.43 & 0.24 & 90 \\
\hline & & 50 & 17.4 & 4.63 & 74 & 9.99 & 3.88 & 61 & 7.17 & 1.00 & 86 \\
\hline & & 60 & 14.8 & 5.77 & 61 & 7.36 & 4.56 & 38 & 2.48 & 0.52 & 79 \\
\hline & $\mathrm{H}$ & 40 & 11.4 & 2.81 & 75 & 7.89 & 1.86 & 76 & 5.77 & 0.55 & 91 \\
\hline & & 50 & 19.8 & 7.92 & 60 & 8.39 & 2.89 & 66 & 5.70 & 0.56 & 90 \\
\hline & & 60 & 14.2 & 8.26 & 42 & 7.23 & 3.46 & 52 & 3.65 & 0.46 & 87 \\
\hline & $\mathrm{M}$ & 40 & 15.0 & 1.92 & 87 & 6.43 & 0.96 & 85 & 12.3 & 0.54 & 96 \\
\hline & & 50 & 23.7 & 11.5 & 51 & 8.16 & 3.11 & 62 & 6.18 & 0.37 & 94 \\
\hline & & 60 & 20.7 & 18.5 & 11 & 6.11 & 4.01 & 34 & 3.75 & 0.45 & 88 \\
\hline \multirow[t]{9}{*}{ G } & NR & 40 & 14.3 & 2.16 & 85 & 6.80 & 1.54 & 77 & 3.93 & 0.63 & 84 \\
\hline & & 50 & 27.0 & 7.37 & 73 & 7.55 & 3.37 & 55 & 6.81 & 0.95 & 86 \\
\hline & & 60 & 14.1 & 5.97 & 58 & 7.31 & 5.07 & 31 & 4.70 & 0.69 & 85 \\
\hline & $\mathrm{H}$ & 40 & 12.7 & 2.48 & 81 & 5.37 & 1.20 & 78 & 3.54 & 0.66 & 81 \\
\hline & & 50 & 24.4 & 7.15 & 71 & 8.76 & 2.83 & 68 & 5.89 & 0.79 & 87 \\
\hline & & 60 & 17.8 & 7.58 & 57 & 8.68 & 3.96 & 54 & 3.82 & 0.45 & 88 \\
\hline & M & 40 & 20.7 & 3.26 & 84 & 7.83 & 1.48 & 81 & 5.40 & 0.30 & 94 \\
\hline & & 50 & 22.3 & 4.85 & 78 & 7.56 & 2.48 & 67 & 6.08 & 0.48 & 92 \\
\hline & & 60 & 15.6 & 5.05 & 68 & 5.31 & 2.73 & 49 & 4.72 & 0.70 & 85 \\
\hline
\end{tabular}

Where: $\mathrm{NO}=$ no osmotic treatment, $\mathrm{S}=$ treatment with sucrose, $\mathrm{G}=$ treatment with glucose, $\mathrm{NR}=$ no pretreatment, $\mathrm{H}=$ pretreatment using hot water at $80{ }^{\circ} \mathrm{C}$ for $10 \mathrm{sec}, \mathrm{M}=$ pretreatment using microwave at $1100 \mathrm{~W}$ for $10 \mathrm{sec}, \mathrm{V} 1=$ fresh volume $\left(\mathrm{cm}^{3}\right), \mathrm{V} 2=$ dried volume $\left(\mathrm{cm}^{3}\right), \mathrm{Sr}=$ shrinkage ratio $(\%)$, Temp $=$ temperature $\left({ }^{\circ} \mathrm{C}\right)$. 

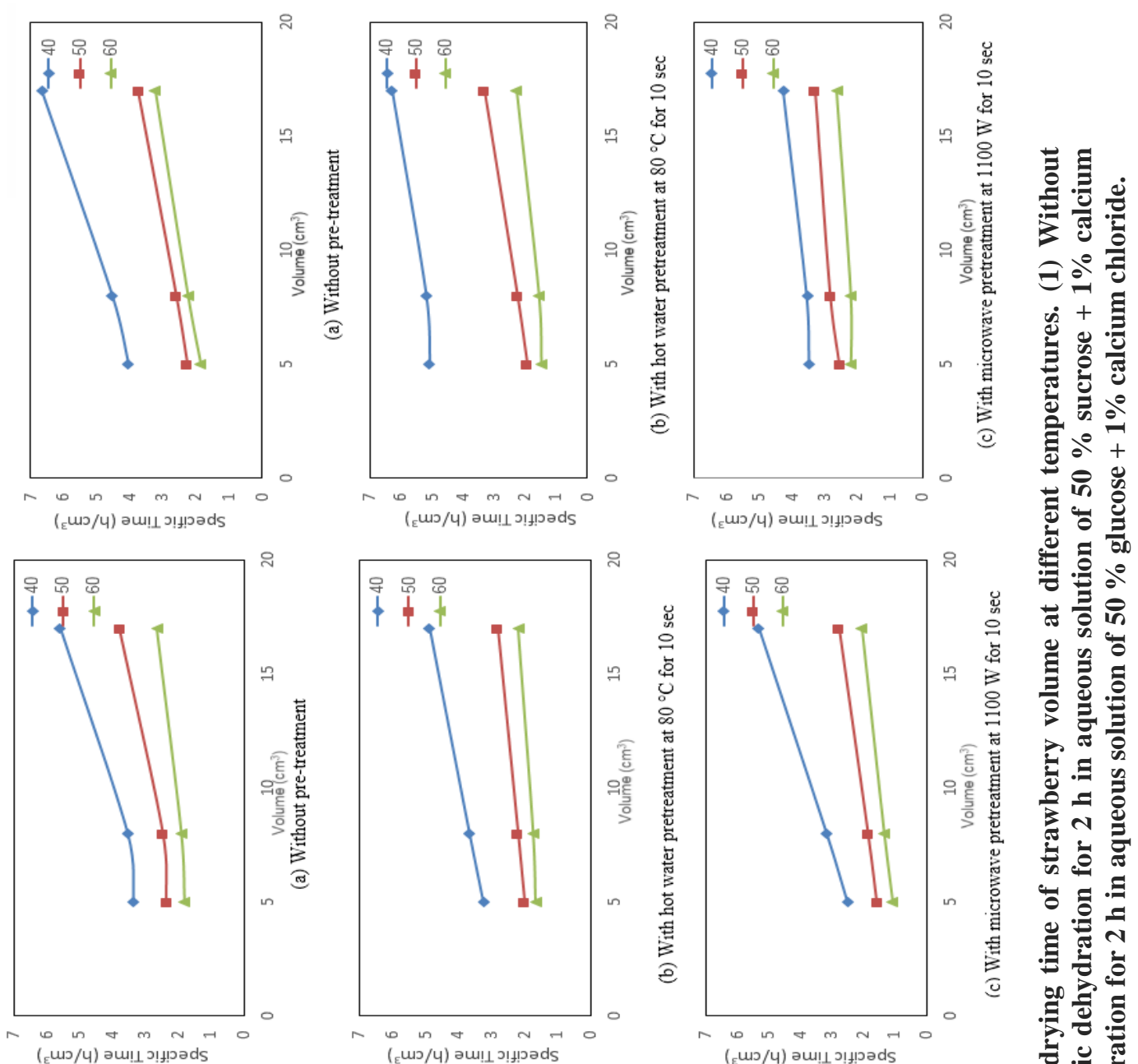

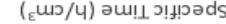
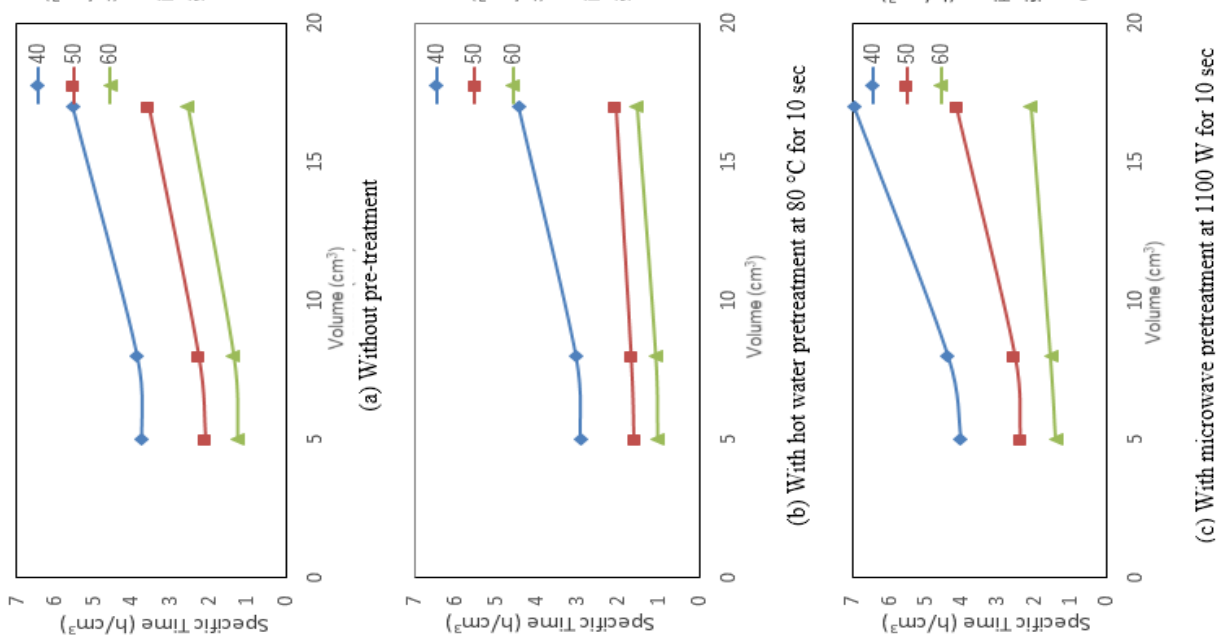

三

\%

象

등 웝.

$>$ ह

응

들

ते

嶑

드으

율

鞄

ํㅣㄹ

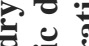

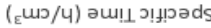

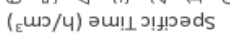

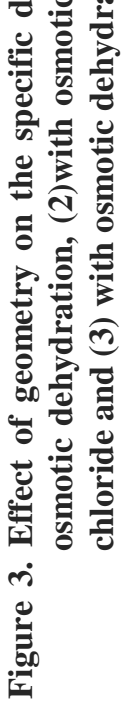


Table 3. The optimum conditions of drying kinetics at the various strawberry geometries and the different pretreatments and temperatures

\begin{tabular}{cclcccc}
\hline $\begin{array}{c}\text { Temp } \\
\left({ }^{\circ} \mathrm{C}\right)\end{array}$ & Pre-treatment & Geometry & Osmo-treatment & $\begin{array}{c}\mathrm{Sr} \\
(\%)\end{array}$ & Df & $\begin{array}{c}\mathrm{STv} \\
\left(\mathrm{h} . \mathrm{cm}^{-3} / \mathrm{cm}^{3}\right)\end{array}$ \\
\hline 40 & NR & Half & Sucrose & 82 & -0.659 & 3.547 \\
& $\mathrm{H}$ & Whole & Sucrose & 75 & -0.649 & 4.897 \\
& $\mathrm{M}$ & Half & Glucose & 81 & -0.665 & 3.541 \\
50 & NR & Half & Glucose & 55 & -0.674 & 2.612 \\
& $\mathrm{H}$ & Whole & Sucrose & 60 & -0.814 & 2.820 \\
& $\mathrm{M}$ & Whole & Sucrose & 51 & -0.668 & 2.789 \\
60 & NR & Half & Sucrose & 38 & -0.516 & 1.911 \\
& $\mathrm{H}$ & Whole & Sucrose & 42 & -0.806 & 2.181 \\
& $\mathrm{M}$ & Whole & Sucrose & 11 & -0.870 & 2.069 \\
\hline
\end{tabular}

Where: $\mathrm{NR}=$ no pretreatment, $\mathrm{H}=$ pretreatment using hot water at $80{ }^{\circ} \mathrm{C}$ for $10 \mathrm{sec}, \mathrm{M}=$ pretreatment using microwave at $1100 \mathrm{~W}$ for $10 \mathrm{sec}, \mathrm{Sr}=$ shrinkage ratio (\%), $\mathrm{Df}=$ drying factor, $\mathrm{STv}=$ specific drying time by volume $\left(\mathrm{h} \cdot \mathrm{cm}^{-3} / \mathrm{cm}^{3}\right)$.

\section{REFERNCES}

Agnieszka, C. and Andrzej, L. 2010. Structural Impact of Osmotically Pretreated Freeze-Dried Strawberries 0n Their Mechanical Properties. International Journal of Food Properties. 13(5):11341149.

Brooks. M. S., Abou El-Hana NH, Ghaly, A. E. 2008. Effects of tomato geometries and temperature on the drying behavior of plum tomato. American Journal of Applied Science 5: 1369-1375.

Chavan, U.D. and Amarowicz, R., 2012. Osmotic dehydration process for preservation of fruits and vegetables. Journal of Food Research, $1(2): 202$.

Erenturk, S., Gulaboglu, M. S., and Gultekin, S. 2005. The effects of cutting and drying medium on the vitamin $\mathrm{C}$ content of rosehip during drying. Journal of Food Engineering, 68.4: 513-518.

FAO .2015. Statistical Database, Food and Agriculture Organization, Rome, Italy.

Ghaly, A., Hammouda, A. and Hattab, M. 2015. Influence of Low Temperature and Geometry on the Drying Behavior and Quality Parameters of Strawberry. International Journal of Bioprocess and Biotechnological Advancements, 1(1):18-30. 
Grabowski, S. and Marcotte, M. 2003. Drying of fruits and vegetables and spices. In: Hand book of postharvest technology: cereals, fruits, vegetables, tea and spices, Chakraverty A, AS. Mujundar and G.S.Y.Raghavan (2ed.). Marcel Dekker, New York: 653-688.

Grove, G. G., Madden, L. V., Ellis, M. A., and Schmitthenner, A. F. 1985. Influence of temperature and wetness duration on infection of immature strawberry fruit by Phytophthora cactorum. Phytopathology, 75.2: 165-169.

Krokida. M. K., Karathanos, V. T., Marouils, Z. B. and Marnos-Kouris M. 2003. Drying kinetics of some vegetables. Journal of Food Engineering 59: 391-403.

Mayor, L., Moreira, R. and Sereno, A.M., 2011. Shrinkage, density, porosity and shape changes during dehydration of pumpkin (Cucurbita pepo L.) fruits. Journal of Food Engineering, 103(1) :29-37.

Menager, I., Jost, M., Aubert, C. 2004. Changes in physicochemical characteristics and volatile constituents of strawberry (Cv. Cigaline) during maturation. J Agric Food Chem 52:1248-54.

Menlik, T., Özdemir, M. B., and Kirmaci, V. 2010. Determination of freeze-drying behaviors of apples by artificial neural network. Expert Systems with Applications, 37(12): 7669-7677.

Nieto, A.B., Salvatori, D.M., Castro, M.A. and Alzamora, S.M., 2004. Structural changes in apple tissue during glucose and sucrose osmotic dehydration: shrinkage, porosity, density and microscopic features. Journal of Food Engineering, 61(2) :269-278.

Noshad, M., Mohebbi, M., Shahidi, F. and Mortazavi, S.A., 2012. Kinetic modeling of rehydration in air-dried quinces pretreated with osmotic dehydration and ultrasonic. Journal of Food Processing and Preservation, 36(5):383-392.

Panarese, V., Laghi, L., Pisi, A., Tylewicz, U., Dalla Rosa, M. and Rocculi, P., 2012. Effect of osmotic dehydration on Actinidia deliciosa kiwifruit: A combined NMR and ultrastructural study. Food chemistry, 132(4) :1706-1712. 
Riediger, N. D., Shooshtari, S., and Moghadasian, M. H. 2007. The influence of sociodemographic factors on patterns of fruit and vegetable consumption in Canadian adolescents. Journal of the American Dietetic Association, 107. 9: 1511-1518.

Vadivambal, R. and Jayas, D.S., 2007. Changes in quality of microwavetreated agricultural products - a review. Biosystems engineering, 98(1) :1-16.

Wiktor, A., Śledź, M., Nowacka, M., Chudoba, T. and Witrowa-Rajchert, D., 2014. Pulsed electric field pretreatment for osmotic dehydration of apple tissue: Experimental and mathematical modeling studies. Drying Technology, 32(4) :408-417.

\section{الملخص العربيى}

\section{تعظيم عميلة تجفيف الفراوله باستخدام معاملات أولية وأشكال هندسية مختلفة عند درجات حرارة منخفضة باسنة}

عبدالقادر غالي' ، عبدالقادر النقيب" ، حسن عبدالمولي" ، خالد ناجي" و عمرو حسن

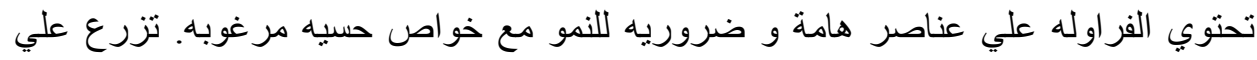

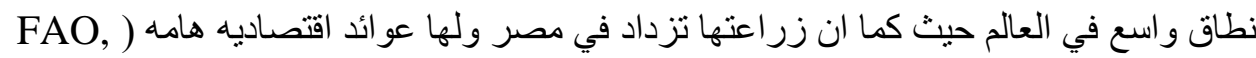

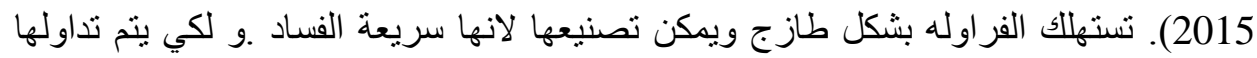
اطول فتره ممكنه محافظة علي خو اصها لهن الطبيعية.

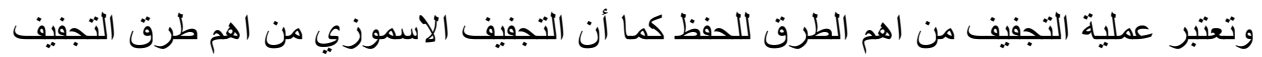

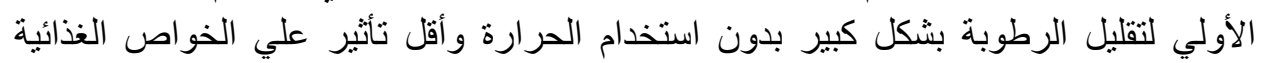

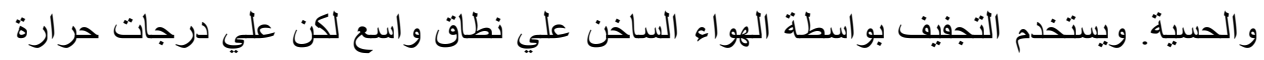

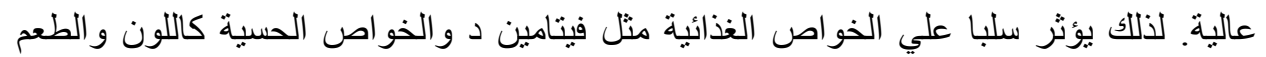

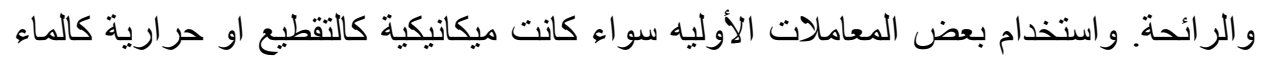
الساخن و الميكروويف يساعد على خفض درجة حر ارة التجفيف المستخدمة. ويهدف البحث الي دراسة بعض العوامل الهندسية المؤثرة علي آلية تجفيف الفراولة و دراسة

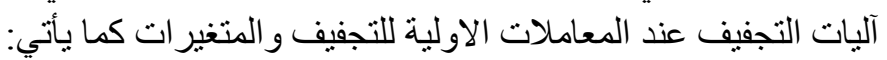

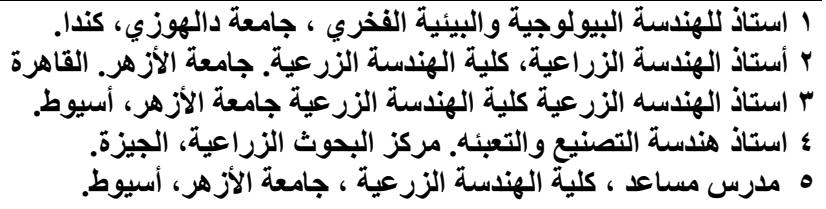

Misr J. Ag. Eng., January 2018 
الثكل الهندسي Geometry (ثمرة كاملة، نصف ثمرة أو ربع ثمرة)

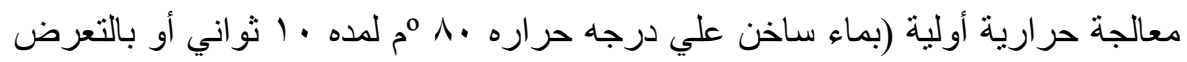

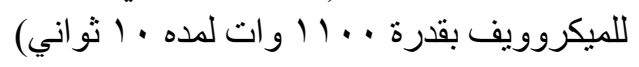

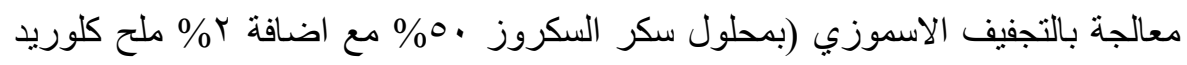

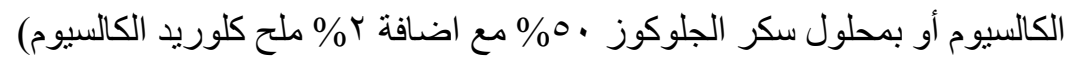

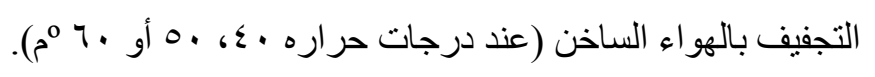

وكانت افضل النتائج كما يأتي:

آنصاف الثمار التي تمت معاملتها فقط بالتجفيف الاسموزي بالسكروز ، كامل الثمره

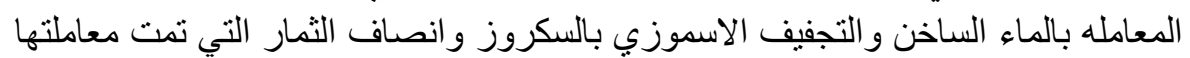

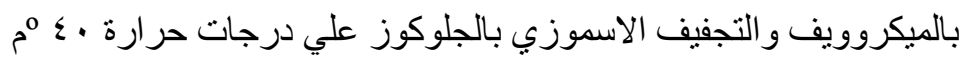

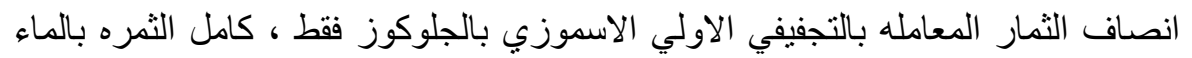

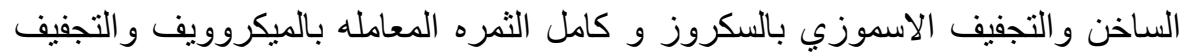

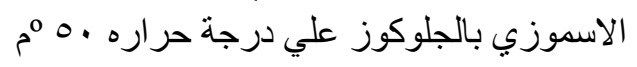

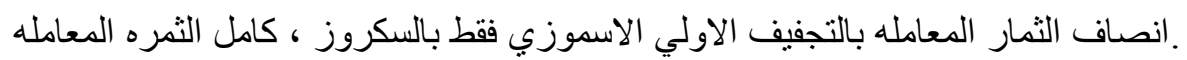

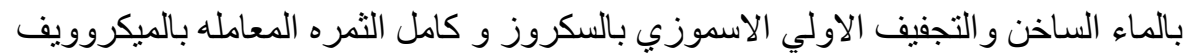

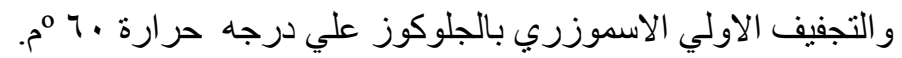

